\title{
Early Bilingual Acquisition: A Case Study in Iran
}

\author{
Elahe Shakhsi Dastgahian ${ }^{1} \&$ Hamid Rostami $^{2}$ \\ ${ }^{1} \mathrm{MA}$ in Linguistics, Iran \\ ${ }^{2}$ International university of Imam Reza, Mashhad, Iran \\ Correspondence: Elahe Shakhsi Dastgahian, MA in Linguistics, Iran. E-mail: edastgahian@yahoo.com
}

Received: August 27, 2013 Accepted: September 23, 2013 Online Published: November 24, 2013

doi:10.5539/ijel.v3n6p97 URL: http://dx.doi.org/10.5539/ijel.v3n6p97

\begin{abstract}
This study takes a look at the acquisition of early bilingualism of Persian and English languages by a five year old boy named Daniel in Iran. It aims to find out the progress he has made while acquiring these languages simultaneously, degree of his success or failure in communication in each language, his code switching and mother tongue dominancy during the five year period since his birth. The result of this study shows that early bilingualism has not caused delay either in Daniel's speech or his language acquisition process. Also it reveals that few code switchings Daniel has made are quite part of his normal language learning process and not indicative of his insufficient knowledge or his difficulty in using and communicating in either language. Moreover, it demonstrates that Daniel's mother tongue has mostly been dominant during the period although Daniel's mother has been communicating with him only in English which is not her first language. For this study, a descriptive method has been used based on his parents' observations, audio and video recordings and taking notes of his bilingual communication developments since his birth.
\end{abstract}

Keywords: bilingual, early acquisition process, mother tongue dominancy, code switching, communication development

\section{Introduction and Background}

It is often believed that bilingualism is the ability to speak two languages with the same fluency the native speakers of two languages speak. Bloomfieldians viewed bilinguals as those who have "native-like control of two languages" (Adebileje, 2013, p. 7). Although bilingual children may go through the same language acquisition stages as the monolingual children do, it is not necessarily the case that they should have a native-like control of two languages. Moderate bilingual researchers have not emphasized on a native-like control over the languages bilinguals are acquiring. Ogunkeye (2007), for example, viewed bilinguals as "individuals who can use at least two languages comfortably, with varying degrees of competence" (cited in Adebileje, 2013, p. 3). Similarly, others like Haugen (1953) defined bilinguals as "individuals who are fluent in one language but who can produce complete meaningful utterances in the other languages" (cited in Butler, \& Hakuta, 2004, p. 114). Many other researchers (e.g., Hakuta, 1986; Macnamara, 1967; Mohanty \& Perregaux, 1997) believed bilinguals show various degrees of proficiency in two languages. Genesee (2003), Patterson and Pearson (2004) believed bilingual children can produce their first words at nearly the same age as monolingual children can.

In their studies of bilingualism, Gawlitzek, Maiwald and Tracy (1996) referred to bilingual children's language mixing which is called code-switching. Bilingual children tend to code switch from one language to another. However, this is a misconception that children learning two languages simultaneously are confused or unable to differentiate between the two languages well.

Children can be bilinguals. Baker (2000) stated that "children are born ready to become bilinguals. They are like sponges, and they can sponge up all languages provided by their environments" (cited in Qismullah, 2009, p. 305). He thought children are capable of picking up any language at home, school or the community they're living in without the impediment of their own first language development. Sometimes, bilinguals learn one language better than the other. In this case, the language a child knows better is the dominant language.

Researches on bilingualism between 1920 and 1960 concluded that bilingualism ends in cognitive deficiencies and lower IQ scores and that bilinguals are nearly three years behind monolingual children in some skills relating to verbal and non-verbal intelligence. Still years after that period, few disadvantages were also reported by 
scholars like Streets (1976) and Brook (2002). Streets (1976) conducted a research on rural bilingual children in Wales. He found that bilingual children were scored relatively lower than monolingual children on IQ tests (Cook, 2002). However, many other researchers like Lambert and Tucker (1972), Ben-Zeev (1977), Rubinand Turner (1989), Bruck and Genesee (1993), Bialystok and Herman (1999), Oller and Pearson (2002) and Dreifus (2011) who claimed a cognitive advantage for bilingual children, have a positive view to bilingualism and early bilingualism. Bilingual development may just be slightly slower than monolingual development, but it does not mean that bilingual children may learn the languages slower, with difficulty or deficiency compared to the monolingual children. Speaking two languages needs ample input and practice. Without practice, the bilinguals may find it difficult to understand or talk to the speakers of either language.

"The bilingual process can begin in the early life of a human and requires a healthy start, sufficient opportunities, and exposure to a care giving environment that allows the child's innate predisposition to learn to communicate to functions" (Rossetti, 2001, cited in Qismullah, 2009, p. 305). Ebert and Hawk (2003) stated that "the linguistic development of children depends upon the linguistic experiences of childhood and the language structures that children encounter" (Cited in Qismullah, 2009, p. 314). Also, as Balkan (1970) suggested, early bilingualism is superior to both monolingualism and later bilingualism. Bialystok and Martin-Rhee (2004) discovered that "children exposed to two languages were quicker at performing a colour and shape sorting task than children who were monolingual" (cited in Adebileje, 2013, p. 7). Also, Bhattacharjee (2012) stated that "bilinguals are more skillful and smarter than monolinguals at solving certain kinds of mental puzzles" (cited in Adebileje, 2013, p. 3).

As it has always been a very interesting idea for many researchers including the researchers in this paper to see if it is possible to raise a bilingual child who is able to communicate in two languages similar to the way native monolingual speakers of each language do, the researchers in this study have tried to provide their child with enough input in English and Persian since his birth to find out about the ease or difficulty with which he would be able to communicate in both languages. It has also been very important for them to see if the child's mother tongue would be the dominant language or not as the child's mother chose to speak with him only in English which was her second language. It made clear that Daniel's language ability has been very approximate to monolinguals in each language. This was rather in contradiction to what was earlier mentioned by extremists like Bloomfieldians or some moderate researchers like Hakuta (1986), Macnamara (1967), Mohanty and Perregaux (1997) and some others. Also, Daniel has shown a very good understanding of the words, sound distinction and pronunciation, etc. in both languages which contradicts Tzouriadou's view. Tzouriadou (1992) believed that "bilingual children show weakness in the comprehension of basic vocabulary or simple utterances and insufficiencies in various aspects of the hearing process, such as discrimination of sounds, combination of phonemes and symbols" (cited in Adebileje, 2013, p. 467).

\section{Methodology}

The acquisition of English and Persian by Daniel did not take place by intentionally instructing him with either language. He was normally exposed to both languages without receiving any direct instructions. The language learning was a normal and easy going process which took place just similar to any first language acquisitions. Daniel went through all the linguistic stages like any other child learning his mother tongue. He has learnt to communicate through natural interactions with his parents although he's been exposed much more to Persian in the environment than English. However, Danny's parents expected that he could attain both languages at a satisfactory level. Despite the worries his parents had, he is now able to take part in conversations in either languages well with only very few imperfections which doesn't hinder his communication.

Only once did his Persian language start to dominate his English language at the age of three when he was spending his first five months in the nursery being exposed to Persian language by other children and people there for six hours a day. And that was the time he had passed the telegraphic stage, and he was to use sentences in Persian more often, then. This made his parents very concerned and apprehended about his slow progress in English language during this short period, and his father started to speak English to him as well on some occasions to fill the gap. But for all the other periods before or after this stage, his English has been rather dominant to Persian up to the present time to the point that he has more code witched to English while speaking Persian than the other way round at the times he has not found the proper word while communicating. That shows the dominant role of his mother tongue, here the English language, which surprisingly was not his mother's first language. Of course, it doesn't mean that Daniel has not been able to communicate in Persian as well as he has done in English.

Although it was psychologically very difficult for Daniel's mother to speak English with him before other people 
in a foreign language setting, she has been consistent in not peaking a word of Persian to him during these five years as she feared that the child might prefer to adhere to Persian language which was heard and spoken all around him much more than English, especially outside home. Even though she was eager to experience this to see if the child would stop speaking English, she never risked to do so.

Daniel was not only exposed to English by his mother at home and everywhere else they were together but also mostly to English cartoons and programmes by the time he has been spending at home for the first four years which made him quite interested in watching English rather than Persian ones afterwards. Undoubtedly, watching English programs had a crucial role in his English language development as the mother was not free to speak to him 24 hours a day.

Daniel was exposed to Persian language by his father everywhere, by his relatives, by people in the nursery or outside home and by Persian parental communications in or outside home. He has also been watching cartoons and programmes in Persian while spending outside or inside home from time to time during the same period. However, during the last year, Daniel has been equally exposed to programmes in both languages.

\subsection{Participants}

Daniel is a five year old boy living in Iran. His parents are teachers of English as a foreign language in Iran. His mother has a Bachelor of Art in teaching English as a foreign language and a Master of Art in linguistics. She is graduated from Iranian universities, and she is teaching English language in Iran. His father has a Bachelor and Master of Art in teaching English as a foreign language. He is also graduated from Iranian universities, and he teaches English. The first language of Daniel's parents is Persian, and they communicate with each other and with all people in Iran in Persian. Iran is a country where English is not spoken outside the English classes and those who plan to learn English in this country don't have a good chance of practicing it outside the classroom. In such a setting, Daniel's parents decided to raise a bilingual child capable of speaking and communicating in Persian and English.

\subsection{Instruments}

This study is done mostly based on the frequent parental observations of Daniel's progress while acquiring two languages at the same time in five years. Meanwhile, his parents did some recordings of his speech at different stages of his bilingual acquisition processes. They have also transcribed many words, phrases and sentences he has produced in either language.

\subsection{Procedure}

Daniel's parents tried to provide him with the normal conditions necessary for the bilingual development despite raising him in a country where English is only a foreign language and seems odd for others to hear it spoken in the environment. Daniel's mother chose to speak only English to him since his birth. And his father has been communicating with him in Persian and rarely in English all throughout this period.

Most important words, phrases and sentences Daniel's parents thought to be helpful data for later report were taken notes of. In some occasions, especially while Daniel has been playing with his toys and was busy talking to himself and his toys, his voice has been recorded without his knowledge. Rarely was he videotaped as he has been aware of video recording most of the time, and this awareness would affect his normal speech production.

Based on the data gathered through the observations, recordings and note takings during five years, Daniel's parents decided to prepare a descriptive report of what and how he has tried to communicate in both languages.

\section{Result and Discussion}

Daniel went through both languages quite satisfactorily and normally. During the first two years, his knowledge and use of English words dominated that of Persian, to the point that he could say and read all the English alphabet letters he learnt indirectly by watching English programmes, and he could count numbers, which he had learnt quite peripherally without any parental interventions, from one to twenty in English, too. It was only a year later that he learnt to count numbers in Persian when he was taught so in the nursery. However, he has not, as of today, practiced or learnt any Persian alphabets.

It was sometimes disappointing for his parents to observe that his vocabulary repertoire was not as developed as that of monolingual children his age, but they also knew the reason was that part of his brain was busy with another language and that was not any sign of difficulty, hindrance or inability in his language acquisition process. The small fluctuation in either language dominance continued by the time he was nearly four. But from then on, he has been able to communicate well in both languages without major difficulties although he prefers English more to Persian now as his mother has spoken only English to him thus far. Now, his vocabulary 
knowledge in every single language even exceeds that of monolingual children his age who speak either language. This supports the idea that bilingualism does not hinder or slow down the acquisition process.

Some developments of words, phrases and sentences in his language acquisition development have been shown in tables below.

Table 1. Persian and English language development in Daniel's first year of age

\begin{tabular}{|c|c|c|}
\hline Danny's progress/problems & English & Persian \\
\hline Number of words & $\begin{array}{l}\text { It was not remarkable, but } \\
\text { collectively in both languages, he } \\
\text { knew as many words as a child } \\
\text { knows in one language. } \\
\text { Sometimes the sound of one } \\
\text { object was used by him to refer } \\
\text { to that object. (e.g., } \\
\text { '[biz]'referred to 'bee'.) }\end{array}$ & $\begin{array}{l}\text { It was not remarkable, but } \\
\text { collectively in both languages, he } \\
\text { knew as many words as a child } \\
\text { knows in one language. Very similar } \\
\text { to his English language, he } \\
\text { sometimes used sounds of objects to } \\
\text { refer to them. (e.g., '[ga:]' for } \\
\text { '[qa:r]' meaning '[kro]', the sound } \\
\text { of crows.) }\end{array}$ \\
\hline $\begin{array}{l}\text { Kind of } \\
\text { words/Phrases/sentences }\end{array}$ & $\begin{array}{l}\text { Up to the end of the first year, } \\
\text { sounds changed into one words, } \\
\text { mostly without a clear or correct } \\
\text { pronunciation. (e.g., '[tad]' for } \\
\text { 'dad', '[bun]' for 'moon', } \\
\text { '[h\&m]' for 'helmet', etc.) }\end{array}$ & $\begin{array}{l}\text { Up to the end of the first year, } \\
\text { sounds changed into one words, } \\
\text { mostly without a clear or correct } \\
\text { pronunciation. (e.g., '[be]' for '[bera } \\
\text { m]' meaning 'go', '[bi]' for '[bija]' } \\
\text { meaning 'come', '[hav]' for '[ha } \\
\text { vapeijma]' meaning 'plane', etc.) }\end{array}$ \\
\hline More frequent sentences & None & None \\
\hline Dominancy & Dominant & Not used as much as English \\
\hline $\begin{array}{l}\text { Degree of code switching } \\
\text { (language mixing) }\end{array}$ & $\begin{array}{l}\text { Very few; of course, he knew if } \\
\text { he was addressed in English or } \\
\text { Persian. He mostly used the } \\
\text { words he knew in English. }\end{array}$ & $\begin{array}{l}\text { Few; he knew if he was addressed in } \\
\text { Persian or English. He used the } \\
\text { words he knew in Persian, but } \\
\text { sometimes he code switched to } \\
\text { English. (e.g., He sometimes used } \\
\text { '[da]' for 'dad' instead of using the } \\
\text { Persian word 'p\&dar', etc.) }\end{array}$ \\
\hline Overextension & $\begin{array}{l}\text { Few. (e.g., 'dad' referred to all } \\
\text { males, 'water' referred to any } \\
\text { liquid, etc). }\end{array}$ & $\begin{array}{l}\text { Few. (e.g., '[am]' for '[amu]' } \\
\text { meaning 'uncle' was used to refer to } \\
\text { every male, '[d3i:z]' meaning } \\
\text { 'dangerous' was used to refer to } \\
\text { every animal, hot things, darkness or } \\
\text { any other kinds of danger). }\end{array}$ \\
\hline Statement sentence problems & No sentences produced & No sentences produced \\
\hline Imperative sentence problems & $\begin{array}{l}\text { One word with a rising tone } \\
\text { (either verbs or nouns) had the } \\
\text { role of a whole imperative } \\
\text { sentence. (e.g., '[wo]' for 'water' } \\
\text { meaning 'give me some water' } \\
\text { or '[h\&p]' for 'help me'.) }\end{array}$ & $\begin{array}{l}\text { One word with a rising tone (either } \\
\text { verbs or nouns) had the role of a } \\
\text { whole imperative sentence. (e.g., '[d } \\
\text { a:]' for '[dar]' meaning 'open the } \\
\text { door'.) }\end{array}$ \\
\hline $\begin{array}{l}\text { Interrogative sentence } \\
\text { problems }\end{array}$ & $\begin{array}{l}\text { Only a rising tone was } \\
\text { accompanied by one word } \\
\text { instead of an interrogative } \\
\text { sentence. (e.g., when someone } \\
\text { rang the door bell, he asked: } \\
\text { '[da:?]' Meaning: 'Is it dad?', } \\
\text { etc.) }\end{array}$ & $\begin{array}{l}\text { The same as English. (e.g., when he } \\
\text { saw the food, he asked: '[baba]' } \\
\text { referring to 'yummy food' and } \\
\text { meaning: 'Is it time to eat food?', } \\
\text { etc.) }\end{array}$ \\
\hline
\end{tabular}




\begin{tabular}{|l|l|l|}
\hline Negative sentence problems & $\begin{array}{l}\text { A rising tone accompanied one } \\
\text { word was used instead of a } \\
\text { negative sentence. (e.g., 'hot' } \\
\text { meant 'I cannot touch it.') }\end{array}$ & $\begin{array}{l}\text { The same as English. (e.g., saying } \\
\text { '[baba]' meaning 'dad' while crying } \\
\text { to show that dad is not here.) }\end{array}$ \\
\hline Word choice problems & $\begin{array}{l}\text { He pointed to things he could not } \\
\text { name. Rarely, did he code } \\
\text { switched to Persian. }\end{array}$ & $\begin{array}{l}\text { He pointed to things he could not } \\
\text { name, or he used the English } \\
\text { equivalent word if he could. }\end{array}$ \\
\hline Use of conjunctions & None & None \\
\hline Use of inflections & None & None \\
\hline Pronunciation problems & $\begin{array}{l}\text { Not few. (e.g., '[hi]' for 'fish', } \\
\text { '[/bu:n]' for 'bloon', '[nap]' for } \\
\text { 'map', '[kai]' for 'sky', etc.) }\end{array}$ & $\begin{array}{l}\text { Not few. (e.g., '[tu:]' for '[tu:p]' } \\
\text { meaning 'ball', '[i:p]' for '[sib]' } \\
\text { meaning 'apple', etc.) }\end{array}$ \\
\hline Other problems & $\begin{array}{l}\text { Pointing to objects he couldn't } \\
\text { name could sometimes } \\
\text { compensate for his lack of } \\
\text { knowledge of English words. }\end{array}$ & $\begin{array}{l}\text { Code switching to English and } \\
\text { pointing to objects he couldn't name } \\
\text { could sometimes compensate for his } \\
\text { lack of knowledge of Persian words. }\end{array}$ \\
\hline
\end{tabular}

Table 2. Persian and English language development in Daniel's second year of age

\begin{tabular}{|c|c|c|}
\hline Danny's progress/ problems & English & Persian \\
\hline Number of words & $\begin{array}{l}\text { It was remarkably increased to } \\
\text { more than } 200 \text { English words. } \\
\text { He knew words like 'octopus', } \\
\text { 'triangle', 'Norway', 'giraffe', } \\
\text { 'peanut' ..., though not with a } \\
\text { clear or very correct } \\
\text { pronunciation. He was rhyming } \\
\text { and playing with words. (e.g., } \\
\text { 'peanut', 'seenot', 'henot', etc., } \\
\text { which were not all English words } \\
\text { or meaningful ones.) }\end{array}$ & $\begin{array}{l}\text { It was remarkably increased but not } \\
\text { as many as English words. He knew } \\
\text { some words used in everyday } \\
\text { conversation though he could not } \\
\text { clearly pronounce them, yet. He } \\
\text { could also rhyme the words in } \\
\text { Persian similar to rhyming in } \\
\text { English. (e.g., '[ali]', '[tali]', } \\
\text { '[mali]', '[pali]', etc. which were not } \\
\text { all meaningful or Persian words.) }\end{array}$ \\
\hline $\begin{array}{l}\text { Kind of } \\
\text { words/Phrases/sentences }\end{array}$ & $\begin{array}{l}\text { He started to use two-word } \\
\text { phrases like 'toothbrush', } \\
\text { 'goodbye', 'sunflower', etc., } \\
\text { again not with a very clear } \\
\text { pronunciation. }\end{array}$ & $\begin{array}{l}\text { He started to use two-word phrases } \\
\text { like '[gaza man]' for '[qazaj\& man]' } \\
\text { meaning 'my food', etc., again not } \\
\text { with a very clear pronunciation. }\end{array}$ \\
\hline More frequent sentences & None & None \\
\hline Dominancy & Rather dominant & Not used as much as English \\
\hline $\begin{array}{l}\text { Degree of code switching } \\
\text { (Language mixing) }\end{array}$ & $\begin{array}{l}\text { Some code switching was visible } \\
\text { although he knew which } \\
\text { language he was addressed. (e.g., } \\
\text { '[zardbol]' meaning 'yellow } \\
\text { ball'). Although he code } \\
\text { switched to Persian, he used the } \\
\text { correct word order in English. } \\
\text { [(Adj+N) in English= (N+Adj) in } \\
\text { Persian.] }\end{array}$ & $\begin{array}{l}\text { Some code switchings were visible } \\
\text { although he knew which language he } \\
\text { was addressed. (e.g.,. '[bUke man]' } \\
\text { meaning 'my book'. Here, he code } \\
\text { switched to English word 'book' for } \\
\text { Persian word '[ketab]', etc.). Again, } \\
\text { code switching did not impede the } \\
\text { Persian word order. }\end{array}$ \\
\hline Overextension & $\begin{array}{l}\text { Not remarkable; he started to } \\
\text { overgeneralise words. (e.g., } \\
\text { sheeps.) }\end{array}$ & $\begin{array}{l}\text { Not remarkable; he started to } \\
\text { overgeneralise words. (e.g., } \\
\text { '[b\&didam]' for '[didam]' meaning } \\
\text { 'I saw'.) }\end{array}$ \\
\hline
\end{tabular}




\begin{tabular}{|c|c|c|}
\hline Statement sentence problems & $\begin{array}{l}\text { He did not produce statement } \\
\text { sentences. Two-word phrases } \\
\text { were used to express a whole } \\
\text { statement sentence. (e.g., 'fire } \\
\text { hot' meaning 'fire is hot.', etc.) }\end{array}$ & $\begin{array}{l}\text { He did not produce statement } \\
\text { sentences. Two-word phrases were } \\
\text { used to express a whole statement } \\
\text { sentence. (e.g., '[ba:f sard]' meaning } \\
\text { 'The snow is cold.', etc.) }\end{array}$ \\
\hline Imperative sentence problems & $\begin{array}{l}\text { One or two words with a rising } \\
\text { tone/intonation were used instead } \\
\text { of a whole sentence. (e.g., } \\
\text { '[buka:]' for 'blue car' meaning: } \\
\text { 'Give me the blue car.', etc.) }\end{array}$ & $\begin{array}{l}\text { He didn't produce sentences. He } \\
\text { used words and phrases with a rising } \\
\text { tone/intonation. (e.g., '[baba de]' } \\
\text { for '[baba bsde]' meaning 'give me } \\
\text { the yummy food.', etc.) }\end{array}$ \\
\hline $\begin{array}{l}\text { Interrogative sentence } \\
\text { problems }\end{array}$ & $\begin{array}{l}\text { He did not produce sentences. } \\
\text { He used words or phrases with a } \\
\text { rising tone/intonation. (e.g., 'dad } \\
\text { car?' Meaning 'Is it dad's car we } \\
\text { heard?', etc.) }\end{array}$ & $\begin{array}{l}\text { He did not produce sentences. He } \\
\text { used words or phrases with a rising } \\
\text { tone/intonation. (e.g., '[bim pak?]' } \\
\text { for '[bsrim park?]' meaning 'Are we } \\
\text { going to the park?', etc.) }\end{array}$ \\
\hline Negative sentence problems & $\begin{array}{l}\text { No sentences were produced. He } \\
\text { added 'no' to words. (e.g., 'no } \\
\text { green' for 'It's not green.', 'no } \\
\text { oval' for 'It's not oval', etc.) }\end{array}$ & $\begin{array}{l}\text { No sentences were produced. He } \\
\text { added '[na]' meaning 'no' to words. } \\
\text { (e.g., [gaza na] meaning 'I don't } \\
\text { want food', etc.) }\end{array}$ \\
\hline Word choice problems & $\begin{array}{l}\text { Not so much problems; he was } \\
\text { able to call the name of most } \\
\text { things. He knew seven } \\
\text { geometrical shapes like 'circle', } \\
\text { 'rectangle', etc. He knew all the } \\
\text { colours and he could make } \\
\text { compound words like 'blue } \\
\text { balloon', etc.). Gestures and } \\
\text { pointing to objects were also } \\
\text { used when he did not know the } \\
\text { words for the new objects. }\end{array}$ & $\begin{array}{l}\text { Not remarkable problems; he was } \\
\text { able to call the name of many things. } \\
\text { However, again his vocabulary } \\
\text { intake was less than that of English. } \\
\text { Gestures, code switching and } \\
\text { pointing to objects were also used } \\
\text { when he did not know the words in } \\
\text { Persian. }\end{array}$ \\
\hline Use of conjunctions & $\begin{array}{l}\text { Few conjunctions like 'and' were } \\
\text { visible at the end of this period. } \\
\text { (e.g., 'dad and mom', 'two and } \\
\text { five', etc.) }\end{array}$ & $\begin{array}{l}\text { Conjunction was an easy process up } \\
\text { to end of this period. He simply } \\
\text { added 'o' for [va] meaning 'and' to } \\
\text { words. (e.g., [sago gobs] for [sag va } \\
\text { gorbs] meaning 'dog and cat', etc.) }\end{array}$ \\
\hline Use of inflections & None & None \\
\hline Pronunciation problems & $\begin{array}{l}\text { He still could not pronounce all } \\
\text { the words correctly, but his } \\
\text { pronunciation had improved. }\end{array}$ & $\begin{array}{l}\text { He still could not pronounce all the } \\
\text { words correctly, especially he could } \\
\text { not pronounce }[\mathrm{q}] \text { and }[\mathrm{x}] \text { sounds in } \\
\text { Persian. However, his pronunciation } \\
\text { had improved. }\end{array}$ \\
\hline Other problems & $\begin{array}{l}\text { He sometimes forgot the name of } \\
\text { objects which were not used } \\
\text { more often. }\end{array}$ & $\begin{array}{l}\text { He sometimes forgot the name of } \\
\text { objects which were not used more } \\
\text { often. }\end{array}$ \\
\hline
\end{tabular}

Table 3. Persian and English language development in Danny's third year of age

\begin{tabular}{|l|l|l|}
\hline Danny's progress/ problems & English & \multicolumn{1}{c|}{ Persian } \\
\hline Number of words & $\begin{array}{l}\text { He was able to use some words } \\
\text { used in everyday conversations } \\
\text { with a satisfactory pronunciation. }\end{array}$ & $\begin{array}{l}\text { He was able to use some words used } \\
\text { in every day conversations with a } \\
\text { satisfactory pronunciation. His } \\
\text { Persian vocabulary intake started to }\end{array}$ \\
\hline
\end{tabular}




\begin{tabular}{|c|c|c|}
\hline & & exceed that of English. \\
\hline $\begin{array}{l}\text { Kind of } \\
\text { words/Phrases/sentences }\end{array}$ & $\begin{array}{l}\text { He used many phrases with } \\
\text { correct word order. (e.g., 'daddy } \\
\text { go car' for 'Daddy went in his } \\
\text { car.', 'cat come Danny' for 'The } \\
\text { cat is coming to } \\
\text { Danny.', 'mommy give ball' for } \\
\text { ' Mommy is giving me the ball.', } \\
\text { 'blue balloon here' for 'The blue } \\
\text { balloon is here.', etc.) }\end{array}$ & $\begin{array}{l}\text { He used many phrases with correct } \\
\text { word order. (e.g., '[ma } \int \text { in berim } \\
\text { park]' meaning, 'Let's go to the park } \\
\text { by car.', etc.) }\end{array}$ \\
\hline More frequent sentences & $\begin{array}{l}\text { He produced long phrases with } \\
\text { correct word order. No sentences } \\
\text { were produced yet. }\end{array}$ & $\begin{array}{l}\text { He produced long phrases with } \\
\text { correct word order. No sentences } \\
\text { were produced yet. }\end{array}$ \\
\hline Dominancy & $\begin{array}{l}\text { It received the same dominancy } \\
\text { as Persian early this age. }\end{array}$ & $\begin{array}{l}\text { It received the same dominancy as } \\
\text { English early this age. It started to } \\
\text { become dominant afterwards by the } \\
\text { time he was nearly four. }\end{array}$ \\
\hline $\begin{array}{l}\text { Degree of code switching } \\
\text { (Language mixing) }\end{array}$ & $\begin{array}{l}\text { Some language mixing was } \\
\text { visible as he knew Persian } \\
\text { language better now. He } \\
\text { sometimes used words in Persian } \\
\text { language when he could not find } \\
\text { a proper word in English. (e.g., } \\
\text { 'daddy car go [tond]' meaning } \\
\text { 'Daddy's car go fast.', etc.) }\end{array}$ & $\begin{array}{l}\text { Up to the end of this period, he did } \\
\text { fewer code switchings to English as } \\
\text { he could speak Persian better than } \\
\text { English. }\end{array}$ \\
\hline Overgereralisation & $\begin{array}{l}\text { Few (e.g., 'Daddy eat water', for } \\
\text { 'daddy drinks water'. May be the } \\
\text { reason was that the same word } \\
\text { 'eating' is used to refer to eating } \\
\text { and drinking in Persian'. Also, } \\
\text { Few overgeneralisations in nouns } \\
\text { and adjectives were visible. (e.g., } \\
\text { moneys, reds, etc.) }\end{array}$ & $\begin{array}{l}\text { Few overgeneralizations were } \\
\text { visible. The word '[qa } \text { 'oq]' meaning } \\
\text { 'spoon' was mostly used for } \\
\text { '[t } \int \text { angal]' meaning 'fork'. }\end{array}$ \\
\hline $\begin{array}{l}\text { Statement sentence } \\
\text { problems }\end{array}$ & $\begin{array}{l}\text { He was still producing phrases } \\
\text { with correct word order. No } \\
\text { statement sentences were } \\
\text { produced. }\end{array}$ & $\begin{array}{l}\text { He was still producing phrases with } \\
\text { correct word order. No statement } \\
\text { sentences were produced. }\end{array}$ \\
\hline $\begin{array}{l}\text { Imperative sentence } \\
\text { problems }\end{array}$ & $\begin{array}{l}\text { Phrases beginning with verbs } \\
\text { were used for an imperative } \\
\text { sentence. (e.g., 'give it to' } \\
\text { meaning 'give it to me, please.', } \\
\text { etc.) }\end{array}$ & $\begin{array}{l}\text { Phrases beginning with verbs were } \\
\text { used for an imperative sentence. } \\
\text { (e.g., '[boro maSin psdar]' meaning } \\
\text { 'get in dad's car.', etc.) }\end{array}$ \\
\hline $\begin{array}{l}\text { Interrogative sentence } \\
\text { problems }\end{array}$ & $\begin{array}{l}\text { No interrogative sentences were } \\
\text { used. Instead, he used phrases } \\
\text { with a rising intonation. (e.g., } \\
\text { 'scared of bee?' meaning 'mom, } \\
\text { are you scared of bees?', etc.) }\end{array}$ & $\begin{array}{l}\text { No interrogative sentences were } \\
\text { used. Instead, he used phrases with a } \\
\text { rising intonation. (e.g., '[do ta } \\
\text { g\&m\&z?]' meaning 'Can I have two } \\
\text { red ones?', etc.) }\end{array}$ \\
\hline Negative sentence problems & $\begin{array}{l}\text { He added 'no' to phrases, } \\
\text { sometimes with a rising } \\
\text { intonation. (e.g., 'no little pink } \\
\text { panther' meaning 'I don't want } \\
\text { the little pink panther doll.', etc.) }\end{array}$ & $\begin{array}{l}\text { '[Na]' meaning 'not' was proceeded } \\
\text { by phrases, sometimes with a rising } \\
\text { intonation. (e.g., '[aksaj\& man na]' } \\
\text { meaning 'Don't touch my pictures.', } \\
\text { etc.) }\end{array}$ \\
\hline
\end{tabular}




\begin{tabular}{|c|c|c|}
\hline Word choice problems & $\begin{array}{l}\text { There were some word choice } \\
\text { problems. He sometimes } \\
\text { preferred to replace English } \\
\text { words with the Persian ones. }\end{array}$ & $\begin{array}{l}\text { Very few problems; he could use } \\
\text { Persian words rather appropriately. }\end{array}$ \\
\hline Use of conjunctions & $\begin{array}{l}\text { He could connect words with } \\
\text { 'and'. (e.g., 'white and red and } \\
\text { purple', etc.) }\end{array}$ & $\begin{array}{l}\text { He used '[o]' meaning 'and' to } \\
\text { connect many verbs and nouns. (e.g., } \\
\text { '[bsrimo bshabim]' meaning 'Let's } \\
\text { go and sleep.', '[sibo porteqalo } \\
\text { moz]' meaning 'apple and orange } \\
\text { and banana', etc.) }\end{array}$ \\
\hline Use of inflections & $\begin{array}{l}\text { Few inflections were used. } \\
\text { ('mommy's shirt', etc.) }\end{array}$ & $\begin{array}{l}\text { More inflections were used in } \\
\text { Persian than in English. }\end{array}$ \\
\hline Pronunciation problems & $\begin{array}{l}\text { Not remarkable; he could even } \\
\text { pronounce } / \Theta / \text { and } / \mathrm{O} / \text { sounds, } \\
\text { which are often difficult for } \\
\text { non-English speakers to } \\
\text { pronounce, quite well. }\end{array}$ & $\begin{array}{l}\text { Very few; he could not pronounce } \\
\text { [q] and [x] sounds. They were } \\
\text { pronounced as [g] and [/h] sounds, } \\
\text { respectively. (e.g., '[gahv\&?i]' for } \\
\text { '[qahv\&?i]' meaning 'brown' and } \\
\text { '[hodam]' for '[xodam]' meaning } \\
\text { 'myself', etc.) }\end{array}$ \\
\hline Other problems & $\begin{array}{l}\text { He had some difficulties finding } \\
\text { some words in English. }\end{array}$ & Not remarkable at this stage \\
\hline
\end{tabular}

Table 4. Persian and English language development in Danny's fourth year of age

\begin{tabular}{|c|c|c|}
\hline Danny's progress/ problems & English & Persian \\
\hline Number of words & $\begin{array}{l}\text { Again English stated to dominate } \\
\text { Persian language. English word } \\
\text { intake increased dramatically. }\end{array}$ & $\begin{array}{l}\text { Persian was not dominant but it was } \\
\text { used properly. A convincing number } \\
\text { of words were used. }\end{array}$ \\
\hline $\begin{array}{l}\text { Kind of } \\
\text { words/Phrases/sentences }\end{array}$ & $\begin{array}{l}\text { He was able to use phrases of } \\
\text { any kinds. Also, sentences were } \\
\text { used by him. }\end{array}$ & $\begin{array}{l}\text { He was able to use phrases of any } \\
\text { kinds. Sentences were also used by } \\
\text { him. }\end{array}$ \\
\hline More frequent sentences & $\begin{array}{l}\text { Imperative and interrogative } \\
\text { sentences were very frequent. A } \\
\text { lot of statement sentences were } \\
\text { used although with some } \\
\text { grammatical imperfections. (e.g., } \\
\text { daddy want to go his car.', etc.) }\end{array}$ & $\begin{array}{l}\text { Imperative and interrogative } \\
\text { sentences were very frequent. A lot } \\
\text { of statement sentences were used } \\
\text { although with some grammatical } \\
\text { imperfections. (e.g., '[man p } \varepsilon \text { sar } \\
\text { hubam]' for '[man pesarexubi } \\
\text { hastam]' meaning 'I'm a good boy.', } \\
\text { etc.) }\end{array}$ \\
\hline Dominancy & English dominated Persian & Not dominant \\
\hline $\begin{array}{l}\text { Degree of code switching } \\
\text { (Language mixing) }\end{array}$ & $\begin{array}{l}\text { Code switching from English to } \\
\text { Persian was visible. (e.g., 'It's } \\
\text { very [tarik]' for 'It's very dark.', } \\
\text { etc.) }\end{array}$ & $\begin{array}{l}\text { Code switching from Persian to } \\
\text { English was frequent. (e.g., 'daddy' } \\
\text { [mige] 'gift' [mihare] meaning } \\
\text { 'Daddy says he will buy a gift.', etc.) }\end{array}$ \\
\hline Overgeneralisation & $\begin{array}{l}\text { His degree of overgeneralisation } \\
\text { was increased. He } \\
\text { overgeneralised the verb } \\
\text { inflections. (e.g., goed, comed, } \\
\text { etc.) And sometimes he } \\
\text { overgeneralised 'he', 'she' } \\
\text { subject pronouns. (e.g., 'mommy } \\
\text { is home. He is here.', etc.). He }\end{array}$ & $\begin{array}{l}\text { He overextended rather than } \\
\text { overgeneralizing some verbs, not } \\
\text { nouns or other parts of speech. (e.g., } \\
\text { He overextended the verb } \\
\text { '[mikonin?]' meaning 'Can you do } \\
\text { it?' to many other situations referring } \\
\text { to 'turning on TV or light', 'helping } \\
\text { him put on his clothes', 'peeling off }\end{array}$ \\
\hline
\end{tabular}




\begin{tabular}{|c|c|c|}
\hline & $\begin{array}{l}\text { could mostly correct himself } \\
\text { when he was pointed to, though. }\end{array}$ & $\begin{array}{l}\text { the fruits', etc.). Corrections were } \\
\text { sometimes ignored by him. }\end{array}$ \\
\hline Statement sentence problems & $\begin{array}{l}\text { Not remarkable; he was able to } \\
\text { produce sentences with rather } \\
\text { correct word choice and } \\
\text { grammatical structure. }\end{array}$ & $\begin{array}{l}\text { Not remarkable; he was able to } \\
\text { produce sentences with rather correct } \\
\text { word choice and grammatical } \\
\text { structure. }\end{array}$ \\
\hline Imperative sentence problems & $\begin{array}{l}\text { None; he was able to produce } \\
\text { imperative sentences well. (e.g., } \\
\text { 'Buy me some cheese puff, } \\
\text { please', 'Let's wash my teddy } \\
\text { bear in the bathroom', etc.) }\end{array}$ & $\begin{array}{l}\text { None; he was able to produce } \\
\text { imperative sentences although he had } \\
\text { a bit of difficulties with some word } \\
\text { choices. (e.g., '[ino pat kon]' } \\
\text { meaning 'put on this one.' but he } \\
\text { meant 'Help me put it on', etc.) }\end{array}$ \\
\hline Interrogative sentence problems & $\begin{array}{l}\text { He only used statement } \\
\text { sentences with a rising } \\
\text { intonation. (e.g., 'We go to } \\
\text { granny's house?', 'It's getting } \\
\text { dark?', 'You buy me a gift?', } \\
\text { etc.) }\end{array}$ & $\begin{array}{l}\text { In Persian, only a change in } \\
\text { intonation changes a statement } \\
\text { sentence into an interrogative one. So } \\
\text { he could easily produce interrogative } \\
\text { sentences using a rising intonation } \\
\text { for a statement sentence. However, } \\
\text { he had some difficulties with verb } \\
\text { choice (e.g.,. '[pedard3un Pino } \\
\text { mituni?]' meaning 'Dad, can you?' } \\
\text { which meant different things (like } \\
\text { 'Can you help me?', Can you put } \\
\text { batteries in the toy car?', 'Can you } \\
\text { take off my shirt?', etc) in different } \\
\text { situations. }\end{array}$ \\
\hline Negative sentence problems & $\begin{array}{l}\text { He mostly used 'not' after verbs. } \\
\text { (e.g., 'Daddy eats not food', 'I } \\
\text { go not to swimming pool', etc.) }\end{array}$ & 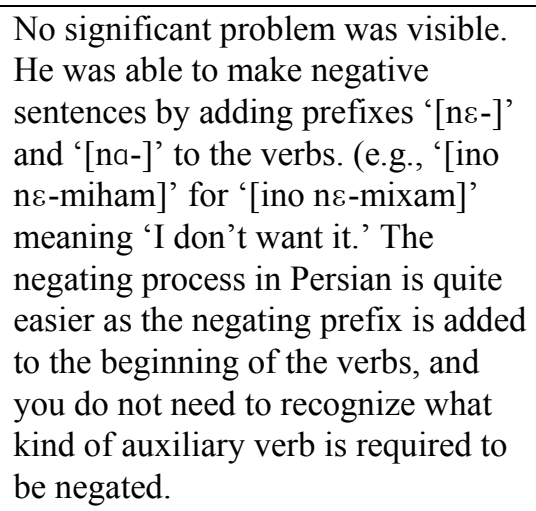 \\
\hline Word choice problems & Very few & few \\
\hline Use of conjunctions & $\begin{array}{l}\text { He could use 'and' and 'when' } \\
\text { to make compound and complex } \\
\text { sentences. (e.g., 'I'm clever and I } \\
\text { play and I love mommy', etc.) }\end{array}$ & $\begin{array}{l}\text { He used '[ba:d]' meaning 'then' to } \\
\text { make compound sentences. (e.g., } \\
\text { '[bazi kardam, ba:d haste Jodam]' } \\
\text { meaning 'I played. Then I got tired.', } \\
\text { etc.) He also used '[vaqti]' meaning } \\
\text { 'when' to make complex sentences. } \\
\text { (e.g., '[vaqti pedard3un bijad, man } \\
\text { bazi mikonam]' meaning 'When } \\
\text { daddy comes, I'll play'. ('[vaqti]' } \\
\text { was the only word in which he could } \\
\text { pronounce[q] sound correctly and } \\
\text { emphatically) }\end{array}$ \\
\hline Use of inflections & $\begin{array}{l}\text { Verb and noun inflection } \\
\text { problems were still in existence. }\end{array}$ & $\begin{array}{l}\text { He had some problems with verbs } \\
\text { and nouns inflections. (e.g., }\end{array}$ \\
\hline
\end{tabular}




\begin{tabular}{|c|c|c|}
\hline & (e.g., 'peoples', 'dranks', etc.) & $\begin{array}{l}\text { '[k\&tabs }]] \text { ' meaning 'her book for' } \\
\text { '[k\&tabam]' meaning 'my book', } \\
\text { etc.) }\end{array}$ \\
\hline Pronunciation problems & $\begin{array}{l}\text { No problems; he could } \\
\text { pronounce all sounds and words } \\
\text { quite well. }\end{array}$ & $\begin{array}{l}\text { He still could not pronounce [q] and } \\
\text { [x] sounds in Persian. They were } \\
\text { replaced by [g]and [h], respectively. } \\
\text { (e.g., '[man gavitaram]' for '[man } \\
\text { qavitaram]' meaning 'I'm stronger', } \\
\text { '[heilihubs]' for '[xeilixubs]' } \\
\text { meaning 'It's great.', etc.) }\end{array}$ \\
\hline Other problems & $\begin{array}{l}\text { Not remarkable; he was able to } \\
\text { communicate in English with } \\
\text { few if any problems, which did } \\
\text { not impede his communication. }\end{array}$ & $\begin{array}{l}\text { Not remarkable; he was able to } \\
\text { communicate in Persian with few if } \\
\text { any problems although he was not } \\
\text { using his Persian language as well as } \\
\text { his English one. }\end{array}$ \\
\hline
\end{tabular}

Table 5. Persian and English language development in Danny's fifth year of age

\begin{tabular}{|c|c|c|}
\hline Danny's progress/ problems & English & Persian \\
\hline Number of words & $\begin{array}{l}\text { His vocabulary intake is } \\
\text { equal to the average } \\
\text { vocabulary intake of } \\
\text { English native speaker } \\
\text { children his age. }\end{array}$ & $\begin{array}{l}\text { He knows many words used in everyday } \\
\text { Persian language. }\end{array}$ \\
\hline $\begin{array}{l}\text { Kind of } \\
\text { words/Phrases/sentences }\end{array}$ & $\begin{array}{l}\text { He is capable of } \\
\text { producing words and } \\
\text { phrases of any kind. } \\
\text { (e.g., 'my blue and black } \\
\text { bicycle', 'a sunny day', } \\
\text { 'a very cold ice cream', } \\
\text { 'auntie Beheshte's new } \\
\text { house', 'not all of them } \\
\text { at the same time', etc.) }\end{array}$ & 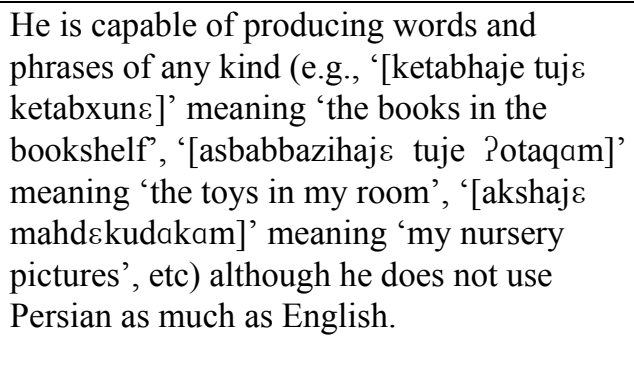 \\
\hline More frequent sentences & $\begin{array}{l}\text { He is able to use words } \\
\text { and phrases used in } \\
\text { everyday conversations, } \\
\text { especially with verbs in } \\
\text { simple and continuous } \\
\text { present/past tense, and } \\
\text { imperative sentences. } \\
\text { (e.g., 'I'm jumping, then } \\
\text { I'm very happy', 'I'm } \\
\text { playing cards', 'I like ice } \\
\text { creams very much', 'I } \\
\text { can tidy up my room', 'I } \\
\text { went to the nursery', 'I } \\
\text { make my bed', 'I want } \\
\text { cold water', 'give it to } \\
\text { me', 'help me', 'come } \\
\text { and play with me', etc.) }\end{array}$ & $\begin{array}{l}\text { He is able to use words and phrases used in } \\
\text { everyday conversation. Very rarely, is he } \\
\text { mixed up with the tense. (e.g., '[man diruz } \\
\text { mihabam]' for '[man diruz xabidam]' } \\
\text { meaning 'I slept yesterday'. Mostly, he uses } \\
\text { simple and continuous present and past tense } \\
\text { verbs and imperative sentences. (e.g., '[man } \\
\text { daram bazi mikonam]' meaning 'I'm } \\
\text { playing', '[dare barun mijad]' meaning 'It's } \\
\text { raining', '[maSinam xarab Sod]' meaning } \\
\text { 'My toy car broke down', etc.) }\end{array}$ \\
\hline Dominancy & $\begin{array}{l}\text { He can speak both } \\
\text { languages well. But his } \\
\text { English is dominant } \\
\text { especially at home. He }\end{array}$ & $\begin{array}{l}\text { His Persian language is satisfactory. Early } \\
\text { this stage, outside home or before other } \\
\text { people, he used to resists speaking English, } \\
\text { and he asked his parents in English to stop }\end{array}$ \\
\hline
\end{tabular}




\begin{tabular}{|c|c|c|}
\hline & $\begin{array}{l}\text { speaks English with his } \\
\text { mother and sometimes } \\
\text { with his Father. When he } \\
\text { plays alone with his toys, } \\
\text { he only uses English to } \\
\text { speak to them. He prefers } \\
\text { story books in English } \\
\text { and can read all of them } \\
\text { in English by heart. }\end{array}$ & $\begin{array}{l}\text { speaking in English. 'Don't make a scene', } \\
\text { he said. Now he doesn't mind if he is alone } \\
\text { or surrounded by others, he speaks in every } \\
\text { language he is being addressed. }\end{array}$ \\
\hline $\begin{array}{l}\text { Degree of code switching } \\
\text { (Language mixing) }\end{array}$ & $\begin{array}{l}\text { He uses very few if any } \\
\text { code switching to Persian } \\
\text { language while speaking } \\
\text { English, and that will be } \\
\text { immediately replaced by } \\
\text { an English word by him. } \\
\text { (e.g., The restaurant is } \\
\text { '[dur]'far away'.) }\end{array}$ & $\begin{array}{l}\text { Few. (e.g., '[man in 'fish' hajeqsrmezro } \\
\text { dust daram]' meaning 'I love these red } \\
\text { fish'.) He usually doesn't mind to replace it } \\
\text { with a Persian word in such a situation, } \\
\text { though. }\end{array}$ \\
\hline Overgeneralisation & $\begin{array}{l}\text { He has still some } \\
\text { instances of } \\
\text { overgeneralization in his } \\
\text { English language. (e.g., } \\
\text { borned, brokened, } \\
\text { childrens, will fell down, } \\
\text { etc.) Also, in some } \\
\text { occasions, when he can't } \\
\text { instantly remember the } \\
\text { proper words, he uses the } \\
\text { phrase 'like this'. (e.g., } \\
\text { 'why is it like this?' for } \\
\text { 'why is there mentally } \\
\text { something wrong with } \\
\text { that person?'). Also, he } \\
\text { uses article 'a' for 'an'. } \\
\text { (e.g., a apple, a egg, etc.) }\end{array}$ & $\begin{array}{l}\text { Overgeneralisation is still in existence in his } \\
\text { Persian. Some of the verbs he used to } \\
\text { overgeneralize at the age of four, are not still } \\
\text { fully recovered. }\end{array}$ \\
\hline Statement sentence problems & $\begin{array}{l}\text { None; he produces } \\
\text { simple and compound } \\
\text { sentences with correct } \\
\text { word choice, word order } \\
\text { and pronunciation. (e.g., } \\
\text { 'mom, I like to tiptoe } \\
\text { because I don't like to } \\
\text { make noise when daddy } \\
\text { is asleep.', etc.) }\end{array}$ & $\begin{array}{l}\text { He is able to make statement sentences } \\
\text { without any major problems. Quite rarely, } \\
\text { does he have a word choice problem. }\end{array}$ \\
\hline Imperative sentence problems & $\begin{array}{l}\text { None (e.g., 'Let me take } \\
\text { a look', 'Wait a minute, } \\
\text { please', 'Help me put on } \\
\text { my shoes, mom.', 'Make } \\
\text { sunny side up for me', } \\
\text { etc.) }\end{array}$ & $\begin{array}{l}\text { Imperative sentences in Persian are mostly } \\
\text { replaced, by him, by the interrogative } \\
\text { sentences. Rarely, does he use the } \\
\text { imperatives in Persian. (e.g., '[be man Pab } \\
\text { midin?]' meaning 'Can you give me a glass } \\
\text { of water?', '[televIzIjun ro } \int \text { an mikonin?]' } \\
\text { meaning 'Turn on the TV, please.', etc. }\end{array}$ \\
\hline $\begin{array}{l}\text { Interrogative sentence } \\
\text { problems }\end{array}$ & $\begin{array}{l}\text { He asks so many } \\
\text { questions. Mostly, he }\end{array}$ & $\begin{array}{l}\text { In Persian, the interrogative sentences are } \\
\text { the statements with a rising intonation. So }\end{array}$ \\
\hline
\end{tabular}




\begin{tabular}{|c|c|c|}
\hline & $\begin{array}{l}\text { uses the statement } \\
\text { sentence with a rising } \\
\text { intonation. (e.g., 'He is } \\
\text { clever?', 'This game is } \\
\text { dangerous?', etc.) In } \\
\text { interrogative sentences } \\
\text { with wh- question words, } \\
\text { he either uses the wh- } \\
\text { word at the end or at the } \\
\text { beginning of a statement } \\
\text { sentence with a rising } \\
\text { intonation or he uses the } \\
\text { verb (sometimes } \\
\text { auxiliary, sometimes } \\
\text { main verb, leaving out } \\
\text { the subject after the wh- } \\
\text { word. (e.g., 'Why is } \\
\text { beating me?', 'Why is } \\
\text { here?', 'Why he has so } \\
\text { many kids?', 'Where he } \\
\text { is going?', 'He is doing } \\
\text { what?', etc.) He also } \\
\text { makes correct } \\
\text { interrogative sentences } \\
\text { with wh-words. (e.g., } \\
\text { 'what time is it?', 'Why } \\
\text { is daddy late?', 'What } \\
\text { are you doing?', etc.) } \\
\text { Only while using } \\
\text { interrogatives starting } \\
\text { with auxiliary verb 'can', } \\
\text { does he mostly use the } \\
\text { correct interrogative } \\
\text { structure. (e.g., 'Can you } \\
\text { read the story books for } \\
\text { me, please?', 'Can he } \\
\text { play?', 'Can you give it } \\
\text { to me?', 'Can you do a } \\
\text { magic?', 'Can you } \\
\text { count?', 'Can you bring } \\
\text { it for me, please?', etc.) }\end{array}$ & $\begin{array}{l}\text { Daniel can make them without any } \\
\text { difficulties. (e.g., '[hava sard } \varepsilon ?] \text { ' meaning } \\
\left.\text { 'Is it cold?', '[t } \int \varepsilon \text { ra hava sard } \varepsilon ?\right] ' \text { meaning } \\
\text { 'Why is it cold?', etc.) }\end{array}$ \\
\hline Negative sentence problems & $\begin{array}{l}\text { None. (e.g., 'I don't want } \\
\text { to wash my face', 'Don't } \\
\text { touch my toys', etc.) }\end{array}$ & $\begin{array}{l}\text { None; he simply adds the negating prefix '[n } \\
\text { a]' to the beginning of Persian verbs. (e.g., } \\
\text { '[man ?\&mruz n\&mixam bsram } \\
\text { mahdskudak]' meaning 'I don't want to go } \\
\text { to the nursery today', etc.) }\end{array}$ \\
\hline $\begin{array}{l}\text { Remarkable word choice } \\
\text { problems }\end{array}$ & $\begin{array}{l}\text { 1- 'he/she' distinction at } \\
\text { early this stage } \\
\text { (recovered now) } \\
\text { 2- 'watch/look' } \\
\text { distinction (rather } \\
\text { recovered) (e.g., 'I want } \\
\text { to look Bambi cartoon.') } \\
3 \text { - do/does distinction for } \\
3^{\text {rd }} \text { person singular }\end{array}$ & $\begin{array}{l}\text { He still has some problems with replacing } \\
\text { 'do' and 'can' for a few verbs like 'turn on, } \\
\text { turn up, down'. (e.g., '[pedard3un, } \\
\text { kampjut\&ro mikonin?]' meaning 'Dear dad, } \\
\text { would you turn up the loudspeaker?', '[ino } \\
\text { mituni?]' meaning 'can you find it for me?', } \\
\text { etc.) }\end{array}$ \\
\hline
\end{tabular}




\begin{tabular}{|c|c|c|}
\hline & $\begin{array}{l}\text { subjects (e.g., 'Why } \\
\text { don't he has a wrist } \\
\text { watch?'). } \\
\text { But for } 1^{\text {st }} \text { and } 2^{\text {nd }} \\
\text { persons, there are no } \\
\text { problems. (e.g., 'I don't } \\
\text { have a marker.', 'We } \\
\text { don't have any chocolate } \\
\text { bars at home.', etc.) }\end{array}$ & \\
\hline Use of conjunctions & $\begin{array}{l}\text { He uses 'and', 'then', } \\
\text { 'when' 'so', 'but' and } \\
\text { 'if'. (e.g., 'It was dark, } \\
\text { then I went to bed'. 'I } \\
\text { was tired and I was } \\
\text { hungry, then I went to } \\
\text { the restaurant to eat.', } \\
\text { 'Yes, when I grow older, } \\
\text { I can buy this car.', } \\
\text { Zippy is a robot, so it's a } \\
\text { he not a she, but Mike is } \\
\text { a boy.', If I go up the } \\
\text { tree, I will 'fell' down., } \\
\text { etc.) }\end{array}$ & $\begin{array}{l}\text { The variety of conjunctions he uses has not } \\
\text { changed since he was four. (e.g., '[man } \\
\text { bidar Jodam, ba?d sobun } 8 \text { xordam]' } \\
\text { meaning 'I woke up, then I ate breakfast', } \\
\text { etc.) Recently he has learned to use } \\
\text { conjunction '[age]' for '[agar]' meaning } \\
\text { 'if'. }\end{array}$ \\
\hline Problems with inflections & $\begin{array}{l}\text { Very few verbs are still } \\
\text { overgeneralised. (e.g., } \\
\text { 'He ates', 'I dranked my } \\
\text { coffee', 'She look at me', } \\
\text { etc.), but he also uses } \\
\text { correct forms: (e.g., 'I ate } \\
\text { it all', 'I drank it', 'I } \\
\text { played', 'She paints } \\
\text { well', etc.) }\end{array}$ & $\begin{array}{l}\text { Few inflections are missing. (e.g., '[man dar } \\
\text { am beram]' instead of '[man daram miram]' } \\
\text { meaning 'I'm leaving', '[man tama } \text { a kona } \\
\text { m]' for' [man tama Sa mikonam]' meaning } \\
\text { 'I'm watching it', etc.) }\end{array}$ \\
\hline Pronunciation problems & $\begin{array}{l}\text { None; he can pronounce } \\
\text { every word, even the } \\
\text { words he hears for the } \\
\text { first time, quite well. }\end{array}$ & $\begin{array}{l}\text { Very few (e.g., He can pronounce }[\mathrm{x}] \text { and } \\
\text { [q] sounds separately. But when he uses } \\
\text { them in words, he still pronounces them } \\
\text { as[h] and [g], respectively. (e.g., '[man } \\
\text { mihabam]' instead of '[man mixabam]' } \\
\text { meaning 'I sleep'.) }\end{array}$ \\
\hline Other problems & $\begin{array}{l}\text { None (He is able to make } \\
\text { sentences with the words } \\
\text { given, and he can } \\
\text { translate them to } \\
\text { Persian). }\end{array}$ & $\begin{array}{l}\text { None (He is able to make sentences with the } \\
\text { words given, and he can translate them to } \\
\text { English). }\end{array}$ \\
\hline
\end{tabular}

As seen in the tables above, during the first year of Daniel's bilingual acquisition, his English was dominant to his Persian language as he was spending more time with his mother than his father at home and elsewhere. Thus, he used to code switch to English while he could not find a proper word in Persian. Code switching to Persian rarely happened when he could not find a proper word in English during this period, though.

From the beginning of language acquisition, Daniel seemed to know which language he'd been communicating in, so he had tried to use the words he knew in the language he was addressed, and it was very clear that he was building a distinct lexicon. This supported the "separate system hypothesis" mentioned by Fromkin, Rodman and Hyams (2007, p. 344). His pronunciation was not very clear and correct, but he was able to communicate in either language with the words he had learnt in each language. 
In the second year, his knowledge of vocabulary and pronunciation grew bigger and he was able to use small phrases to express a whole sentence meaning. So, he did not have any significant problems while communicating in either language, and his acquisition process looked quite normal. His code switching in each language did not impede his knowledge of grammatical structure and word order. And it proved that he was developing separate grammar, too. Also, he was able to pronounce $/ \Theta /$ and $/ O /$ sounds in English quite well. His ability to pronounce these sounds, which do not exist in Persian language and are very difficult to pronounce by English language learners in Iran, showed that he was developing two separate sound systems, as well. In the third year, he was more exposed to Persian for a short period when his Persian language got dominant, but he was still able to communicate in English while being addressed in this language.

Later at the age of four, his English developed greatly, and he was able to use a variety of English sentences and communicate well in this language. Although he had some minute grammatical problems like inflectional problems, for example, it was not a sign of difficulty in his acquisition process. At the same time, he could communicate quite satisfactorily in Persian language using many sentences with few grammatical or word choice problems.

Now, at the age of five, Daniel seems not to have any significant problems while making sentences which are often used. But when he wants to use a new sentence or one which is used less, he faces some overgeneralization problems with the questioning, inflections, etc.

It seems his degree of overgeneralization has increased as he has acquired each language more. For instance, while communicating in English at four, he used the sentence 'I'm tired' correctly, but at five, when he learnt to use adverbs like, quickly, slowly, etc., he sometimes adds suffix -ly to many adjectives and makes 'tiredly', 'fastly', 'cleverly', etc. Similar problems have been observed in Persian, too. The overgeneralisation is still in existence in his both languages. However, it's not a sign of hindrance in acquisition process either in English or Persian. He has been able to use each language quite satisfactorily, keeping each language separate while communicating. However, some aspects of his speech like an increase in his overgeneralisation or existence of it in five year period and the type of interrogative sentences he uses in English, for example, and the possible consequences of his communication with his mother in Persian require more investigations in the future.

\section{Conclusion}

Daniel has been able to use both languages quite satisfactorily as he has been able to express himself well in each language. A bit of language delay in the first years was not a matter of concern about his language development and it proves De Houwer, Petitto and Holowka's belief that there are no significant delays or disorders in language acquisition of bilinguals.

Although Daniel still code switches and his overgeneralization has increased since the start of his language acquisition, his communication abilities have been drastically enhanced during the five year period. Daniel has been capable of interacting in either language quite normally and similar to that of monolingual children his age. His step by step language development has been part of language learning process and there were not any signs of inability or difficulty in his language acquisition. He is now a bilingual child who has developed language skills very approximate to that of other monolingual children his age and he can use and communicate in each language as appropriate as every monolingual child can do in one language. Also, compared to monolingual children his age, Daniel seems to have developed better analytical and problem-solving skills, creativity and concentration.

\section{Acknowledgement}

We would like to thank Mrs Beheshte Shakhsi Dastgahian for proofreading most parts of this article.

\section{References}

Adebileje, A. (2013). Bilingualism in the ESL classroom: A blessing or a curse. International journal of education and research, 3 .

Baker, C. (2000). Parents and Teachers' Guide to Bilingualism (2nd ed.). Clevedon: Multilingual Matters Ltd.

Ben-Zeev, S. (1977). The influence of bilingualism on cognitive strategy and cognitive development. Child Development, 48(3), 1009-1018. http://dx.doi.org/10.2307/1128353

Bhattacharjee, Y. (2012). Why Bilinguals are Smarter. Sunday Review. The New York Times. Retrieved from http://the-benefits-of-bilingualism.html

Bialystok, E., \& Herman, J. (1999). Does bilingualism matter for early literacy? Bilingualism. Language and Cognition, 2(1), 35-44. http://dx.doi.org/10.1017/S1366728999000139 
Bialystok, E., \& Martin-Rhee, M. (2004). Attention and inhibition in bilingual children: Evidence from the dimensional change card sort task. Developmental Science, 7, 325-339. http://dx.doi.org/10.1111/j.1467-7687.2004.00351.x

Bruck, M., \& Genesee, F. (1993). Phonological awareness in young second language learners. Unpublished manuscript, McGill University.

Butler, Y., \& Hakuta, K. (2004). Bilingualism and second language acquisition. In T. Bhatia, \& W. Ritchie (Eds.), The Handbook of Bilingualism (p. 114). Blackwell Publishing Ltd.

Cook, V. (2002). Portraits of the L2 user. New York: Multilingual Matters.

De Houwer, A. (1999). Two or More languages in Early Childhood. Some general points and practical recommendations. Washington Dc: Centre for applied linguistics. Retrieved March 4, 2005, from www.cal.org/resources/digest/earlychild.html

Dreifus, C. (2011). The Bilingual Advantage. Science. The New York Times. Retrieved from http://www.nytimes.com/science

Ebert, O., \& Hawk, W. (1998). An Overview of Second Language Acquisition. Retrieved June 12, 2004, from http://www.eslkidstuff.com/Articles.htm

Fromkin, V., Rodman, R., \& Hyams, N. (2007). An Introduction to Language (8th ed., p. 344). Boston, USA: Thomas higher education.

Gawlitzek, M., \& Rosemarie, T. (1996). Bilingual Bootstrapping. Linguistics, 34, 901-926.

Genesee, F. (2003). Bilingualism and language impairment. In R. D. Kent (Ed.), MIT. Encyclopedia of Communication Disorders (pp. 275-278). Cambridge, MA: MIT Press.

Hakuta, K. (1986). Mirror of Language: The Debate on Bilingualism. New York: Basic Books.

Haugen, E. (1953). The Norwegian Language in America. Philadelphia: University of Pennsylvania Press. http://dx.doi.org/10.2307/409974

Lambert, W., \& Tucker, G. R. (1972). Bilingual education of children; The St. Lambertexperiment. Rowley, Mass: Newbury House Publishers.

Macnamara, J. (1967). The bilingual's linguistic performance: A psychological overview. Journal of Social Issues, 23, 59-77. http://dx.doi.org/10.1111/j.1540-4560.1967.tb00576.x

Mohanty, A. K., \& Perregaux, C. (1997). Language acquisition and bilingualism. In J. W. Berry, P. R. Dasen, \& T. S. Saraswathi (Eds.), Handbook of Cross-Cultural Psychology: Vol. 2. Basic Processes and Human Development (pp. 217-253). Boston, MA: Allyn and Bacon.

Ogunkeye, O. (2007). Bilingualism and the teaching of English and French. Nigeria Journal of Social \& Cultural Studies. Retrieved from http://contextjournal.wordpress.com

Oller, D. K., \& Pearson, B. Z. (2002). Assessing the effects of bilingualism: A background. In D. K. Oller, \& R. E. Eilers (Eds.), Language and literacy in bilingual children (pp. 3-21). New York: Multilingual Matters.

Patterson, J. L., \& Pearson, B. Z. (2004). Bilingual lexical development: Influences, contexts and processes. In B. A. Goldstein (Ed.), Bilingual language development and disorders inSpanish-English speakers (pp. 77-104). Baltimore, MD: Paul H. Brookes.

Petitto, L., \&Holowka, S. (2002). Evaluating Attributions of Delay and Confusion in Young Bilinguals: Special insights from infants acquiring a signed and a spoken language. Sign language studies, 23, http://dx.doi.org/10.1353/sls.2002.0025

Qismullah, Y. (2009). A case study on infant bilingual acquisition. MJAI, 305.

Rossetti, L. M. (2001). Communication Intervention: Birth to Three (2nd ed.). Canada:Thompson Learning.

Rubin, H., \& Turner, A. (1989). Linguistic awareness skills in grade one children in a Frenchimmersion setting. Reading and Writing. An Interdisciplinary Journal, 1(1), 73-86. http://dx.doi.org/10.1007/BF00178839

Tzivinikou, S. (2004). Developmental speech problems and bilingualism: The difficulties of identification. International Education Journal, 5(4), 467.

Tzouriadou, M. (1992). Speech Disorders. Thessaloniki: Aristotle University Publications. 


\section{Copyrights}

Copyright for this article is retained by the author(s), with first publication rights granted to the journal.

This is an open-access article distributed under the terms and conditions of the Creative Commons Attribution license (http://creativecommons.org/licenses/by/3.0/). 